\title{
The Effect of Audit Committee's Effectiveness on Dividend Payout Policy: Evidence from the Jordanian Firms
}

\author{
Khalil Nimer (Assistant Professor) \\ Accounting Department, Applied Science University \\ Shafa Badran, Amman 11931, Jordan \\ E-mail: k_nimer75@hotmail.com \\ Lina Warrad (Assistant Professor) \\ Accounting Department, Applied Science University \\ Amman 11931, Jordan \\ Ola Khuraisat (Assistant Professor) \\ Accounting Department, Applied Science University \\ Amman 11931, Jordan
}

Received: December 31, 2011

Accepted: February 3, 2012

Published: April 1, 2012

doi:10.5539/ijbm.v7n7p172

URL: http://dx.doi.org/10.5539/ijbm.v7n7p172

\begin{abstract}
This paper examines the possible association between audit committee's effectiveness and Jordanian industrial public shareholding companies' dividend payout policy. Data was collected through two sources; first, a questionnaire survey was distributed to 63 listed Jordanian firms to collect data concerning degrees of audit committees' effectiveness. Second, data concerning dividends payout policies was collected from published data for Jordanian firms. The results of the multiple regressions indicated that there is no significant relationship between audit committees' effectiveness factors and dividends payout policies proxied by both TOBINS Q and ROA. This result implies that other theories might explain the dividend payout policy in the Jordanian firms.
\end{abstract}

Keywords: Dividend policy, Audit committee's effectiveness, Amman Stock Exchange (ASE)

\section{Introduction}

Audit committees are a key institution in the context of corporate governance because they help boards of directors fulfill their financial and fiduciary responsibilities to shareholders. Through their audit committees, boards of directors establish a direct line of communication between themselves and internals, external auditors, and the chief financial officer. Such an organizational structure and reporting responsibility in an environment of free and unrestricted access enables full boards of directors to achieve their goals and policies (Bean, 1999 and Abbot et al, 2004).

In 1999, the Blue Ribbon Committee (BRC) made 10 recommendations for improving audit committees' effectiveness. BRC also provided five broad guiding principles for audit committees to follow in devising company-specific policies. The BRC recommendations resulted in changes by NASDAQ, the NYSE, AMEX, and the SEC. In 2002, the Sarbanes-Oxley Act increased audit committees' responsibilities and authority, and raised membership requirements and committee composition to include more independent directors. In response, the SEC and the stock exchanges proposed new regulations and rules to strengthen audit committees (Annemarie et al, 2004).

Jordan, although it is one of the developing countries, it has a well organized financial market that is Amman Stock Exchange (ASE) with a 202 listed corporations. This market was established in 1979, and was developed over the last three decades from financial, regulatory, and legislative perspectives. The Jordanian business law and the Security Exchange Committee (SEC) regulations established a corporate governance code in 1999 in 
which establishing audit committees were the core of it. Therefore, all listed corporations were obliged to establish audit committees that enable boards of directors not only to gain assurance about the quality of financial reporting and audit processes, but also to approve of significant accounting policy decisions such as dividend payout policy (www.asc.com.jo).

The dividend policy decision involves determining the amount of earnings to be distributed to stockholders or to retain them for reinvestment in the firm. The basic stock price model $\quad \mathrm{P} 0=\mathrm{D} 1 / \mathrm{ks}-\mathrm{g}$ shows which will tend to increase the price of the stock. However, if cash dividends are increased, then less money will be available for reinvestment, the expected future growth rate will be lowered, and this will depress the price of the stock. Thus, changing the dividend has two opposing effects.

The optimal dividend policy for the firm is that balances between currents dividends and future growth which maximizes the price of the stock. The firms take into account for broad categories of factors which effect dividends policy such as constraints on dividend payment, investment opportunities, availability and cost of alternative sources of capital and effects of dividend policy on Ks. Accordingly, the main aim of this paper is to examine whether audit committee's effectiveness effect dividend payout policy in the Jordanian firms (Mancinelli et al 2006).

\section{Research Problem}

This study is an attempt to provide empirical evidence insight into corporate governance theories through examining the relationship between audit committees' effectiveness and the payout policy in one of the developing countries. Jordan seems to be a suitable case study to examine such an issue, as it has one of the earliest stock exchange markets in the region with a 202 listed corporations. In addition, the existing studies often fail to find statistically significant effects of audit committee's effectiveness on firm performance and dividends payout policy in developed countries.

\section{Literature Review}

Although researches that examined the relationship between audit committees effectiveness and payout policies are rare, several studies examined the effect of different corporate governance aspects on payout policies. For example, Chen and Steiner (1999) employed a nonlinear simultaneous equation methodology to examine how managerial ownership relates to risk taking, debt policy, and dividend policy. Their results have implications for their understanding of agency costs. The result supports the argument that managerial ownership helps to resolve the agency conflicts between external stockholders and managers but at the expense of exacerbating the agency conflict between stockholders and bondholders. They further observe evidence of substitution-monitoring effects between managerial ownership and debt policy, between managerial ownership and dividend policy, and between managerial ownership and institutional ownership. In addition, Mancinelli et al (2006) investigate the relationship between dividend policy and ownership structure using a sample of 139 listed Italian companies. The results of the empirical analysis revealed that firms make lower dividend payouts as the voting rights of the largest shareholder increase. Sawicki (2009) traced corporate governance practices in five East Asian countries: Hong Kong, Indonesia, Malaysia, Singapore and Thailand, over the period 1994 to 2003, documenting substantial improvements following the Asian financial crisis. There is some evidence that dividends act as a substitute for other corporate governance mechanisms prior to the crisis, however a strong positive relationship between governance and dividends emerges post-crisis. The relationship is incremental to the effect of legal regime, confirming that shareholder protection at the firm level is important to forcing firms to disgorge cash in an outcome model of dividends. Ramli (2010) investigates the effect of large shareholders and dividend policy of Malaysian companies using panel data from 2002 to 2006. With the concentration on ownership structure in Malaysia, they analyzed the relevant agency conflicts that arise from the relationship between large shareholders and minority shareholders. The result shows that companies make higher dividend payout as the shareholding of the largest shareholder increase. The magnitude of dividend payout is also larger when there is a presence of the substantial second largest shareholder in the company. Chen and Dhiensiri (2009) analyzed the determinants of the corporate dividend policy using a sample of firms listed on New Zealand Stock Exchange (NZSE). Their findings provide strong support to the agency cost theory and partially support transaction cost and residual dividend theory. In addition, dividend payout ratio is positively related to the degree of ownership dispersion and negatively related to the degree of insider ownership. They also found that firms that experience recent growth in revenues tend to pay lower dividends. There is a weak evidence to support the imputation tax credit hypothesis. Lawson B., et al. (2011) examined the relationship between auditor monitoring and dividend payout policy. Based on previous studies which demonstrated that dividends mitigate agency concerns between investors and management and auditors mitigate agency conflicts by reducing information asymmetry between insiders and 
investors. They propose two competing theories to predict the association between auditor monitoring and dividend payouts: the outcome and substitution theories. The outcome theory predicts stronger auditor monitoring is associated with greater dividend payouts, while the substitution theory predicts a negative association. Their results indicate a negative association between auditor monitoring and dividend payouts and appear robust to several sensitivity analyses. These results support the substitution theory of dividend payouts and suggest investors view stronger auditor monitoring as an alternative governance mechanism to dividend payouts in reducing agency conflicts between managers and shareholders. Finally, Baker (2011) made an attempt, through a questionnaire survey, to provide evidence regarding factors that might impact dividends payout policies in Indonesian firms. He surveyed managers in 52 listed corporations in the Indonesian Stock Exchange because it is one of the largest stock exchanges in Asia. The evidence revealed that managers view the most important determinants of dividends as the stability of earnings and the level of current and expected future earnings. They also believed that the effects of dividends on stock prices and needs of current shareholders are important determinants. The evidence, also have shown that managers of Indonesian firms perceive that dividend policy affects firm value. Managers seem to agree that multiple theories including signaling, catering, and life cycle explanations help to explain why their firms pay dividends

Within the Jordanian environment, very few studies made attempts to examine the relationship between corporate governance aspects and dividend payouts policy. Abu-Tapanjeh, A. (2006) examined the association between specific corporate practices with firm's operating structure and Financial Performance. He examined 39 Industrial companies listed in Amman Stock Exchange, over the period of 1992 to 2004. The study employed two factors of management performance, i.e., Operating Performance measured by Net Sales to Operating Cost and Financial Performance measured by Dividend Payout Ratio as a model specification in order to test the hypotheses. The full regression statistical results showed that the proportion of non-Executive Directors (BOD), the general manager acting dual role as Chairman of Board of Directors $(\mathrm{GMCH})$, the Gearing Ratio, and the firm size were significantly correlated with firm operating and Financial Performance, whereas the Gearing Ratio (GEAR) in case of Financial Performance and Family Members on Board (FMOB) showed insignificant effect on the firm's performance. Also, within the context of the Jordanian environment, lately, Warrad L. et al. (2011) examined the possible association between ownership structure and Jordanian industrial public shareholding companies' dividend payout policy. They examined the payout behavior of dividends for Jordanian industrial public shareholding companies over the period 2005-2007. The results consistently support the evidence that there is a positive significant relation between foreign ownership structure and the dividends payout policy through Tobin's Q. Moreover, the results documented significant relationship between foreign ownership structure, company size and debt ratio with dividends policy measured by return on assets (ROA).

\section{Model and Hypothesis Development}

The set off point of this research was to determine how to examine the degree of effectiveness of audit committees in the Jordanian firms. Reviewing literature in this field revealed that on 1999, the Blue Ribbon Committee on Improving the Effectiveness of Corporate audit committees (BRC) made 10 recommendations for improving audit committees' effectiveness. BRC also provided five broad guiding principles for audit committees to follow in devising company-specific policies. The BRC recommendations resulted in changes by NASDAQ, the NYSE, AMEX, and the SEC. In addition, in 2002, the Sarbanes-Oxley Act increased audit committees' responsibilities and authority, and raised membership requirements and committee composition to include more independent directors. Accordingly, these recommendations, which were provided by the above mentioned bodies, were taken into consideration in designing a questionnaire survey that was distributed to the Jordanian firms in order to examine the degree of audit committees' effectiveness in the Jordanian firms. The proxies that were used to examine this independent variable were similar to those employed in several previous studies (see for example, Harley McHutchison, 2003 and Swaiki, 2009). They include the number of audit committee's members, audit committee's organizational structure, audit committee's independence, procedures and resources, audit committee's responsibilities, and financial reporting and compliance.

The other main variable of this research was the dividends payout policy which was designed as a dependent variable. This variable was examined massively in literature within different context and through several proxies. In a pioneering effort, Black (1976) found no convincing explanation of why companies pay cash dividends to their shareholders. Since that introduction of the "dividend puzzle," a voluminous amount of research offers alternative and appealing approaches to solve it. Most of them are rooted in information asymmetries between firm insiders and outsiders, and suggest that firms may indicate their future profitability by paying dividends. Gómes (1996), Fluck (1998), Myers and Majluf (1984) recognized that dividend policies address agency problems between corporate insiders and shareholders. Grossman and Hart (1980) pointed out that the dividend 
payouts mitigate agency conflicts by reducing the amount of free cash flow available to managers, who do not necessarily act in the best interests of shareholders. In line with that, Jensen (1986) argued that a company with substantial free cash flows is inclined to adopt investment projects with negative net present values. If managers increase the amount of dividend, all else being equal, it reduces the amount of free cash flows, thereby mitigating the free cash flow problem. Thus, dividend payouts may help control agency problems by getting rid of the excess cash that otherwise could result in unprofitable projects. Furthermore, Easterbrook (1984) argued that dividends help alleviate agency conflicts by exposing firms to more frequent monitoring by the primary capital markets because paying dividends increases the probability that new common stock has to be issued more often. This, in turn, leads to an investigation of management by investment banks, security exchanges, and capital suppliers.

Accordingly, similar to the previous studies within this context, the main explanatory variables for dividend policy are the return on assets (ROA) and Tobin's q ${ }^{1}$. Return on assets was included as an accounting measure that is beyond management manipulation and shows a balance-sheet effect. It is calculated at the firm level as the earnings before interest and taxes (EBIT) over total assets. The advantage of this measure is that it is not influenced by the liability structure of the corporation, as it excludes interest payments and financial income. The ratio reflects the availability of resources to distribute once investment funding is secured, which should increase dividend payments. Tobin's q reflects expectations about future earnings and market perceptions about the value of the company. Companies' demand of funds for further investments is represented by a high Tobin's q value, which should have a negative impact on dividends.(Note 1)

From the research design, and audit committees' effectiveness proxies, the following hypotheses were developed in order to achieve the main objectives of this research:

$\mathbf{H}_{01}$ : There is a relationship between audit committee organizational structure and firm's dividend payout policy.

$\mathbf{H}_{\mathbf{0 2}}$ : There is a relationship between audit committee independence and firm's dividend payout policy.

$\mathbf{H}_{03}$ : There is a relationship between audit committee membership, procedures and resources and firm's dividend payout policy.

$\mathbf{H}_{04}$ : There is a relationship between audit committee responsibilities and firm's dividend payout policy.

$\mathbf{H}_{05}$ : There is a relationship between financial reporting and compliance and firm's dividend payout policy.

\section{Data and Sample}

Data related to the dependent variable (i.e., dividends payout policy) were collected from secondary resources represented by the published financial reports of the listed Jordanian industrial companies.

In order to examine the audit committee's effectiveness, a questionnaire survey was designed and distributed to the research sample. The sample is constructed from all the listed Jordanian companies in Amman Stock Exchange (ASE). Most of the previous studies used questionnaire survey to obtain information on audit committees' effectiveness mailed to audit committees' members in the Corporations. However, due to the nature of the research population, the personally administered approach was the most appropriate for this research, as postal questionnaire were uncommon method in Jordan where people ignore it most of the time and due to the inefficiency of the Jordanian post. Therefore, it was a crucial step that to establish a key person in each company, through friends, relatives, and business relationships, in order to be able to get access and meet the required person. This step was time and cost consuming in which make it very difficult to meet all the listed industrial firms. Therefore, seventy (70) industrial Jordanian companies representing several Corporate Governance models have been conducted personally between January and June 2011. A total of sixty three (63) firms accepted to respond and completed the questionnaire survey, representing $(90 \%)$ as responding rate of the conducted sample.

The questionnaire was pre-tested through a pilot study which was conducted with a random sample of ten firms. A draft questionnaire was used with a semi-structured list of questions that allowed managers to raise any matters they believed to be relevant, thus making it easy to refine the final questionnaire. This step aimed at minimizing the risk of understanding between the researcher and the respondent and helping to ensure the appropriateness of questions for the final questionnaire, in particular, whether they reflect all the uncovered issues at this stage.

The final draft of the questionnaire was designed based on an ordinal scale which was employed through five points Likert Scales, and included six sections and covering letter. Broadly, the first section was concerned with general information about the firm and the respondent; the second section was concerned with the audit 
committee organizational structure; the third section was related to audit committee independence; the fourth section examined audit committee procedures and resources; the fifth section was concerned with audit committee responsibilities, and the sixth section was dedicated to examine the financial reporting and compliance.

Similar to all previous studies a Crombach Alpha test was employed to examine the internal reliability of the questionnaire, as it is the recommended test when questionnaires are designed from a set of questions (De Vaus, 2002). Table (1) summarizes the results of Crombach Alpha test and have shown that internal reliability for each domain and for all the questions of the audit committee effectiveness was higher than the reference value which is (0.68) (Devaus, 2002).

\section{The Descriptive Analysis}

In order to analyze data which was collected through the questionnaire survey, Means and Standard Deviations were the descriptive statistical techniques that were employed. The results for each domain of the audit committee effectiveness were presented the table (2).

Table (2) shows the values of mean and Standard Deviation for each domain of audit committee effectiveness. Clearly, most of the Jordanian respondents indicated that the organizational structure of their audit committees meet the requirements of audit committees' effectiveness, as this domain was ranked as the highest by the Jordanian respondents with 3.48 mean, and 0.73 as a standard deviation. The other domains, except the independency, were also ranked as applicable domains by the majority of the Jordanian respondents with (3.33), (3.28) and (3.25) means respectively as it was indicated in table (2). This was clear in the respondents' answers as they indicated that audit committees accomplish their responsibilities, all the required procedures and resources are reported and followed, and finally, they indicated that the financial reports are reviewed and assessed by the audit committees. On the other hand, most of the respondents provided negative indicators toward independency of audit committee's members, as this domain was ranked as the poorest among audit committees' effectiveness' domains with a mean of 1.88 and standard deviation of 1.09 .

\section{Regression Analysis}

The second step of data analysis was to explore the effect of audit committees' effectiveness on dividends policy in the Jordanian firms. As it was indicated previously, dividend policy was proxied by two variables; TOBIN'S $\mathrm{Q}$ and ROA. Simple linear regressions were employed to examine the effect of audit committees' effectiveness, represented by the five mentioned domains, on dividend policy, represented by TOBIN'S Q and ROA. Tables (3) and (4) revealed the results of linear regressions between audit committees' effectiveness' factors with TOBIN'S $\mathrm{Q}$ and ROA.

As it is clear in tables (3) and (4), the results of the simple linear regression analysis for the effect of audits committee effectiveness' components on TOBIN'S Q and ROA suggested no significant effect for these components on Tobin's Q or ROA. However, organizational structure has shown the highest results, which support the previous discussion that Jordanian companies paid attention toward the structure of audit committees from the number of members or members' missions and responsibilities perspectives. These results contradict with the results of both Abu Tabanja (2006) and Warrad et al (2011) but consistent with the results of Lawson et al (2011) and Baker (2011). These results were surprising because the results of researches that conducted in Jordan contradicted with our results and studies that conducted in different environment were consistent with our results. This could be attributed to several explanations such as that previous studies in Jordan examined the effect of other corporate governance features on dividends payout policy like Board of Directors and different ownership structure whereas this study examined the effect of audit committees' effectiveness. In addition, different methods approached the other two researches as they relied on published data whereas this study relied on a questionnaire survey. On the other hand, the consistency of our results with the results of Baker (2011) and Lawson et al (2011) comes from the consistency of their results with the dividends payout theories which demonstrate that dividends payout policies cannot be attributed to a single factor, as it is relied on the companies and economy situations and addition to the managers strategies.

\section{Results Discussion}

As this study aims at examining the effect of audit committees' effectiveness on dividends payout policy, the descriptive and regression analysis were employed to examine whether there are significant relationships between the five factors that determined the degree of effectiveness of audit committees in Jordanian firms and dividends payout policies that were proxied by TOBINS Q and ROA.

The descriptive analysis indicated that Jordanian respondents ranked first, organizational structure of the audit 
committees, followed by identifying the responsibilities of audit committees, and audit committees' procedures and finally monitoring and controlling the financial statements. However, the average mean for each of these four components does not exceed (3.48). In addition, the last component of audit committees' effectiveness, which was the independency of audit committee members, had the weakest mean (1.88). These results could be attributed to the fact that Jordanian firms construct audit committees as a response to Security Exchange regulations, which forced all listed corporations to have audit committees that monitor and control the companies' management and ensure their independency. However, the performance of these committees seem to be poor and ineffective due to the restrictions on audit committees' members' work and the weak independency of their members as the results have shown. These results was supported by data obtained from the published financial reports, as this data indicated that most of the audit committees' members have relationships with the board of directors and the management of the firms. These results were not a surprise as the domain ownership form in Jordan is the family business, which provides additional evidence to these results.

Accordingly, it is clear that Jordanian firms pay their attention to the legal perspectives such as the audit committees' structures, procedures and instructions ignoring the substance of these committees' work, which is monitoring and controlling the management performance to protect investors' interest especially small investors. This mission would never be accomplished as long as the members of audit committees were not completely independents.

The second step of the analysis was examining the audit committees' effectiveness components on dividends payout policies in Jordanian firms. The results of the linear regressions suggested no relationships between any of these components and the proxies employed to examine the dividends payout policies which are TOBIN'Q and ROA. However, audit committee's structure have shown the highest relationship, although it was insignificant, which supported the previous discussion concerning the concentration of Jordanian firms on the legal perspectives ignoring the substance work for these committees.

\section{Conclusions and Implications}

This study examined the relationship between audit committees' effectiveness and dividends payout policy in the Jordanian listed firms. Audit committees' effectiveness data was collected through a questionnaire survey that was distributed to a total of seventy industrial Jordanian firms, in which (63) of them accepted to respond to the questionnaire survey representing a $(90 \%)$ responding rate. Consistent with similar previous studies, dividends payout policy were proxied by TOBINS Q and ROA, which their data was collected from the published financial reports of these companies. Multiple regression analysis was employed to examine the effect of audit committees' effectiveness domains on dividends payout policies in the Jordanian firms.

The results indicated that none of the audit committees' effectiveness domains show significant effect on dividends payout policies in Jordan proxied by both TOBINS Q and ROA. These results was attributed to the lack of independency of audit committees' members, as this factor was ranked as least among audit committees' effectiveness domains and other domains were ranked around the means which indicated that Jordanian firms focus on the organization and procedures of their audit committees ignoring the substance of these committees which is the independency of their members to practice their work efficiently. Accordingly, this study could imply that dividends payout policies in Jordan could be explained by different factors other than the audit committees' effectiveness.

\section{References}

Abbott, L. J., Parker, S., \& Peters, G. F. (2004). Audit committee characteristics and restatements. Auditing, 23(1), 69-87.

Abu-Tapanjeh. M. (2006). "Good Corporate Governance Mechanism and Firms' Operating and Financial Performance: Insight from the Perspective of Jordanian Industrial Companies". Working Paper. Faculty of Business Administration, Mutah University, Karak - Jordan.

Annemarie K. Keinath and Judith C. Walo. (2004). [Online] Available: http://www.nysscpa.org/cpajournal/2004/1104/essentials/p22.htm

Baker, H. (2011). Dividend Policy in Indonesia: Survey Evidence from Executives. Journal of Asia Business Studies, Vol. 6 Iss: 1

Bean, J. W. (1999). The audit committees roadmap. A.I.C.P.A

Black F. (1976). The dividend puzzle. Journal of Portfolio Management, 2: 5-8. http://dx.doi.org/10.3905/jpm.1976.408558 
Chen, C.R., \& Steiner, T.L. (1999). Ownership and agency conflicts: a non-linear simultaneous equation analysis of managerial ownership, risk taking, debt policy, and dividend policy. The Financial Review, 34, pp. 119-136. http://dx.doi.org/10.1111/j.1540-6288.1999.tb00448.x

Chen, J and Dhiensiri, N. (2009). Determinants of Dividend Policy: The Evidence from New Zealand. International Research Journal of Finance and Economics, ISSN 1450-2887 Issue 34 (2009).

De Vaus, D. (2002). Analyzing Social Science Data. London, SAGE.

Easterbrook F. H. (1984). Two agency-cost explanations of dividends. American Economic Review, 74: 650-659.

Fluck Z. (1998). Optimal financial contracting: debt versus outside equity. Review of Financial Studies, 11: 383-418. http://dx.doi.org/10.1093/rfs/11.2.383

Fred. W, Eugene F. Brigham. (2010). Essentials of Managerial Finance, (tenth edition.). Harcourt Bracc and Company International Edition.

Gómes A. (1996). The dynamics of stock prices, manager ownership, and private benefits of control. Manuscript, Harvard University, Cambridge, MA.

Grossman S., and O. Hart. (1980). Disclosure laws and take-over bids. Journal of Finance, 35: 323-334. http://dx.doi.org/10.2307/2327390

Jensen M. (1986). Agency costs of free cash flow, corporate finance, and takeovers. American Economic Review, 76: 323-329.

Lawson B., \& Wang D. (2011). Auditor Monitoring and Dividend Payout Policy. (March 13, 2011). [Online] Available: http://ssrn.com/abstract $=1786948$

Mancinelli, Luciana, and Aydin Ozkan. (2006). Ownership structure and dividend policy: Evidence from Italian firms. The European Journal of Finance, 12, 265-282. http://dx.doi.org/10.1080/13518470500249365

Myers, S.C., and Majluf, N. S. (1984). Corporate financing and investment decisions when firms have information that investors do not have. Journal of Financial Economics, 13, 187-221. http://dx.doi.org/10.1016/0304-405X(84)90023-0

Ramli, N. M. (2010). Ownership Structure and Dividend Policy: Evidence from Malaysian Companies. International Review of Business Research Papers, Vol. 6, No. 1, 170-180.

Sawicki. J. (2009). Corporate Governance and Dividend Policy in Southeast Asia Pre- and Post-Crisis. European Journal of Finance, V15: 2: 211-230.

Warrad L., Abed S., Khriasat O., and Al-Sheikh I. (2011). The Effect of Ownership Structure on Dividend Payout Policy: Evidence from Jordanian Context. The Editorial Board of International Board of Economics and Finance, Canadian center of science and education.

[Online] Available: http://exchange.jo/sites/default/files/Corp_Govern_Code.pdf

\section{Note}

Note 1. Tobin's q: is a ratio comparing the market value of a company's stock with the value of a company's equity book value. The ratio was developed by James Tobin (Tobin 1969). It is calculated by dividing the market value of a company by the replacement value of the book equity:

Tobin's q $=$ (Equity Market Value + Liabilities Book Value)

(Equity Book Value + Liabilities Book Value) 
Table 1. Cronbach Alpha results for internal consistency reliability for each domain of the audit committee effectiveness

\begin{tabular}{|l|c|c|}
\hline Domain & Number of items & Cronbach Alpha \\
\hline Organization & 3 & 0.700 \\
\hline Independent & 8 & 0.798 \\
\hline Procedure & 11 & 0.876 \\
\hline Responsibility & 25 & 0.954 \\
\hline Complaisance & 16 & 0.956 \\
\hline Total & 63 & 0.953 \\
\hline
\end{tabular}

Table 2. The means and SD for each domain of audit committee's effectiveness

\begin{tabular}{|l|c|c|c|c|}
\hline Domain & Mean & SD & $\%$ & Skewness \\
\hline Organizational structure & 3.48 & 0.73 & 69.6 & 0.4 \\
\hline Independency & 1.88 & 1.09 & 37.6 & 1.2 \\
\hline Procedures & 3.25 & 1.27 & 65.0 & 0.0 \\
\hline Responsibilities & 3.33 & 0.64 & 66.6 & 0.5 \\
\hline Complaisance & 3.28 & 0.70 & 65.6 & 0.1 \\
\hline Total & 3.04 & 0.62 & 60.8 & 0.2 \\
\hline
\end{tabular}

Table 3. The results of the simple linear regression between audits committees' effectiveness factors and dividend policy represented by TOBIN'S Q

\begin{tabular}{|c|c|c|c|c|c|c|}
\hline Dividend policy (Tobin's Q) & $\mathrm{r}$ & $\mathrm{R}^{2}$ & $\mathrm{~F}$ value & $\operatorname{sig}(\mathrm{f})$ & $\mathrm{T}$ & $\operatorname{sig}(\mathrm{t})$ \\
\hline Organization & 0.141 & 0.020 & 1.09 & 0.300 & 1.04 & 0.300 \\
\hline Independence & 0.095 & 0.009 & 0.48 & 0.488 & 0.69 & 0.488 \\
\hline Procedure & 0.091 & 0.008 & 0.45 & 0.505 & 0.67 & 0.505 \\
\hline Responsibility & 0.044 & 0.002 & 0.10 & 0.749 & 0.322 & 0.749 \\
\hline Compliance & 0.001 & 0.000 & 0.00 & 0.992 & 0.009 & 0.992 \\
\hline
\end{tabular}

Table 4. The results of the simple linear regression between audits committees' effectiveness factors and dividend policy represented by ROA

\begin{tabular}{|c|c|c|c|c|c|c|}
\hline Dividend policy (ROA) & $\mathrm{r}$ & $\mathrm{R}^{2}$ & $\mathrm{~F}$ value & $\operatorname{sig}(\mathrm{f})$ & $\mathrm{T}$ & $\operatorname{sig}(\mathrm{t})$ \\
\hline Organization & 0.212 & 0.045 & 2.54 & 0.117 & 1.59 & 0.117 \\
\hline Independence & 0.051 & 0.003 & 0.14 & 0.709 & 0.37 & 0.709 \\
\hline Procedure & 0.159 & 1.39 & 0.243 & 0.243 & 1.18 & 0.243 \\
\hline Responsibility & 0.077 & 0.006 & 0.32 & 0.572 & 0.56 & 0.572 \\
\hline Compliance & 0.035 & 0.001 & 0.06 & 0.797 & 0.25 & 0.797 \\
\hline
\end{tabular}

